\title{
Apresentação
}

\section{DOSSIÊ: Sublimação}

Um célebre personagem de Jorge Luis Borges imbuiu-se de uma tarefa tão inusitada quanto impossível: escrever (sem transcrevê-lo, evidentemente) um livro publicado trezentos séculos antes.

Pierre Menard pretendia recriar o Dom Quixote -"palavra por palavra e linha por linha" - não por total identificação a Cervantes, mas através da sua própria experiência - a de um escritor do século XX -, o que tornava seu projeto bem mais árduo que o do autor original. Entre eles havia todos os complexíssimos fatos transcorridos nesse entretempo, incluindo o próprio Quixote.

As indagações impostas ao campo psicanalítico pelo conceito de sublimação nos remete à ambição de Menard. Com um agravante: o que se poderia pensar do projeto de se recriar um texto idêntico aquele de cuja existência temos notícia, mas que, desaparecido antes de ser publicado, nunca foi lido por ninguém?

Segundo a introdução do editor inglês James Strachey aos "artigos sobre metapsicologia", encontrados no volume XIV da Standard Edition, Freud teria redigido, em 1915, e logo destruído, sete outros ensaios que comporiam o seu conjunto. Um dos manuscritos perdidos versaria sobre a sublimação. Com o seu desaparecimento, dispomos apenas de algumas indicações, preciosas, porém, na maioria das vezes, enigmáticas, distribuídas ao longo da obra freudiana.

Pode ser que a sublimação tenha sido de fato escrita; cabe-nos escrevê-la.

É consenso que a elucidação do processo sublimatório permanece uma lacuna no corpo teórico da psicanálise. A noção tem sido utilizada pelos psicanalistas como uma espécie de conceito coringa - necessário para o alcance epistemológico pretendido pelo saber psicanalítico - que promoveria a costura entre a dimensão metapsicológica da obra de Freud, seus textos culturais, seus ensaios sobre a criação artística, com destaque para a literária e, mesmo, sua teoria da clínica, para os que consideram que a sublimação estaria no horizonte de um tratamento psicanalítico bem sucedido na promoção de processos de simbolização. No entanto, apenas mais recentemente assistimos a um esforço por parte de representantes da comunidade psicanalítica em buscar o rigor teórico necessário para que a sublimação possa adquirir todo o potencial interpretativo que parece efetivamente deter. 
Nesse dossiê, inspirado no evento "Sublimação e recurso à força: desafios da cultura contemporânea",' ocorrido no IPUSP em novembro de 2009, contamos com a contribuição de pesquisadores que vêm se destacando nos estudos sobre a sublimação.

O primeiro artigo é assinado por Sophie de Mijolla-Mellor, autora de obras de referência relativas à sublimação publicadas originalmente na França. Nele o leitor encontrará uma reflexão acerca da relação da sublimação com o campo do narcisismo, mais especificamente com a constituição dos ideais, e uma aproximação do trabalho sublimatório com o trabalho de desidealização promovido pelo humor. Para Sophie de Mijolla-Mellor, na sublimação o sujeito tem sucesso em promover uma "ereção do eu no eu", ao mesmo tempo em que elabora o luto pelos objetos idealizados da infância. Além disso, o leitor encontrará uma sugestão bastante criativa de compreensão do papel da pulsão de morte no processo sublimatório.

No ensaio seguinte, Ana Cecília Carvalho dá seqüência às suas pesquisas na interface da psicanálise com a literatura abordando a presença da destrutividade na obra do escritor norte-americano Davis Foster Wallace. Por meio de uma leitura da segunda teoria freudiana do conflito pulsional, a autora formula uma "toxidez da escrita" como destino possível da sublimação, ilustrada por fragmentos dos textos de Wallace que antecedem seu suicídio. Dessa maneira, aspectos funcionais e desfuncionais da criação literária são examinados em correspondência com as operações de fusão e desfusão pulsionais implicadas no processo sublimatório.

Transpondo a discussão para o campo do poder e da governabilidade, Joel Birman percorre um espectro bastante amplo do discurso freudiano acerca do laço social e das vicissitudes do mal-estar na civilização, buscando demonstrar de que maneira o conceito de sublimação se fez necessário para problematizar a inserção do sujeito da pulsão e do desejo na ordem sociocultural que o acolhe e o interpela. Nesse sentido, seu ensaio - que sistematiza a concepção de sublimação elaborada ao longo da sua obra - empreende uma leitura acerca da força nos escritos de Freud e de suas relações com a filosofia política e com o pensamento sobre a guerra constituídos na modernidade.

Já o ensaio de Fabio Landa é dedicado à poética na clínica psicanalítica, entendida como a emergência de processos criativos a partir do acolhimento do testemunho de alguém que sofre. Transitando entre as fronteiras da psicanálise, da filosofia e da literatura, e recorrendo a um conjunto bastante heterogêneo de autores - de Ferenczi a Derrida, de Nicolas Abraham a Emmanuel Lévinas e Paul Celan - o autor tece os fios das suas

1 Organizado pelos professores Nelson da Silva Jr., Ana Maria Loffredo, Daniel Kupermann e Nelson Ernesto Coelho Jr., junto aos discentes Joana Sampaio Primo, Luiz Eduardo de Vasconcelos Moreira, Mariana Fontoura Terra Bento, Pedro Eduardo Silva Ambra, Raphael Gelas e Vanessa Lopes dos Santos Passarelli, do Instituto de Psicologia da USP, e financiado pela Fapesp. 
inspirações em um texto que apela para a escuta sensível do leitor. Afinal, se o poema é uma "garrafa ao mar", como escreve Celan, a poética psicanalítica depende de que alguém, numa praia distante, se disponha a decifrar sua mensagem.

Finalmente, o artigo de Clarissa Metzger e de Nelson da Silva Junior, que conclui esse dossier, empreende uma leitura rigorosa dos aspectos metapsicológicos implicados no processo sublimatório, configurando seu campo problemático em torno do problema da desfusão pulsional que acompanha a sublimação e dos destinos da pulsão de morte, seja na singularidade de cada sujeito, seja no campo da cultura. Os autores exploram, portanto, o paradoxo freudiano segundo o qual a sublimação configuraria a base sobre a qual se apóia a civilização e, também, causa da destrutividade nessa mesma ordem sociocultural.

Ao final do percurso, acreditamos que o leitor de Psicologia USP sairá enriquecido pelo acompanhamento dos trabalhos que compõem este dossier, não tanto de certezas adquiridas, mas da convicção de que se depara com um conceito decisivo para o enfrentamento ético, estético e político dos desafios que nos são impostos pela contemporaneidade.

Finalmente, não poderíamos deixar de agradecer a Thais Fontana Gemignani e a Lizana Dallazen pelo cuidado na revisão dos originais.

Daniel Kupermann

\section{Referências}

Borges, J. L. (2010). Pierre Menard, autor do Quixote. In J. L. Borges, Ficções. São Paulo: Companhia das Letras.

Strachey, J. (1980). Introdução do editor inglês. In S. Freud, Edição standard das obras psicológicas completas de Sigmund Freud (Vol. 14). Rio de Janeiro: Imago. (Trabalho original publicado em 1969) 
